\title{
Wind Action Analysis on Different Structures of Photovoltaic Systems Installed on Flat Rooftops of Buildings
}

\author{
D. G. N. M. Benchimol, J. L. Domingos e A. J. Alves \\ Experimental \& Technological Research and Study Group (NExT) of \\ Federal Institute of Goiás, Goiânia, Goiás, Brazil \\ e-mail: danielgbenchimol@gmail.com, jose.domingos@ifg.edu.br, aylton.alves@ifg.edu.br
}

\begin{abstract}
This paper aims to analyze the velocities and pressures that the wind exerts in three different configurations of photovoltaic systems installed on flat rooftops of buildings. The Finite Element Method is used to perform thirty computer simulations for different wind speeds and directions. From the obtained results analyzes of the maximum and minimum values of pressure and velocity on the surface of the structures and the building are performed. Thus, it is possible to identify the necessary precautions regarding materials and installation so that the structure is safe and does not result in accidents and material and economic damage.
\end{abstract}

\section{Key words}

Photovoltaic panel; wind actions; pressure and speed

\section{Introduction}

The increase in installed capacity of photovoltaic systems in Brazil in 2018 represents fifty percent of a total of 2.4 GW of installed capacity today. Most of the installations are tied to distributed micro and mini generation, which correspond to electric power generation systems with an installed capacity of $75 \mathrm{~kW}$ or less, and above $75 \mathrm{~kW}$ and less than or equal to $5 \mathrm{MW}$, respectively. In this context, a stimulus is observed that the systems are installed on the gr-nd or integrated into the buildings. In the latter case, for buildings in the design phase it is already possible to predict the mechanical loads that the photovoltaic system will exert on the roofs of the buildings. In the case of existing buildings, assessments are required on the mechanical carrying capacity of the system to be installed [1], [2], [3]. In this context, studies are conducted to analyze the effect of wind on flat roofs of buildings. Therefore, the characteristic wind values in Brazil are evaluated, based on ABNT NBR 6123 - Wind Forces in Buildings [4], in order to parameterize computational simulations that allow the analysis, having as objectives: i) to evaluate photovoltaic systems structures with varying amounts of panels, defining the occupation of the available coverage area; ii) identify the effects of wind velocity by assessing the pressures exerted on the panels and the fixation structures of the panels; iii) identify the worst situations involving wind speed and direction in photovoltaic system structures installed on flat roofs of buildings; iv) apply the Finite
Element Method to obtain wind pressure on the structures of photovoltaic systems.

\section{Methodology}

The methodology proposed in this work includes the computational simulation of three configurations for the arrangement of photovoltaic panels on flat roofs, varying the amount and placement of the panels on the roof plan of the building. From the three defined configurations, as for the positioning and number of panels, thirty simulations are performed associating wind speed and direction over the building.

The computational modeling initially foresees the construction of the geometry that contains the photovoltaic structure, the building and the physical environment in which the structure a and the building are inserted, thus defining the context to be analyzed. Afterwards, the obtained geometry is used for simulations that consider the wind actions on the building and photovoltaic panels, using software based on the Finite Element Method [5]. Figure 1 shows the geometries defined for the simulations, where the plan of the building roof can be identified and a structure with $\mathrm{f}-\mathrm{r}$ panels on the left, with eight panels in the center and five with eight panels each on the right.

To perform the computer simulations, the software configuration presupposes the definition of the fluid flow condition in laminar and / or turbulent regime. For these simulations, turbulent flow is defined, given that the wind reaching different structures does not maintain its uniform movement. One of the characteristics of this turbulent movement is the higher average velocity near the surface of the structure.

The equations solved by the Turbulent Flow k- $\varepsilon$ interface are the Navier-Stokes equations for momentum conservation and the continuity equation for mass conservation. Turbulence effects are modeled using the standard two-equation model $\mathrm{k}-\varepsilon$ with constraints of realization. To perform the simulations is used the

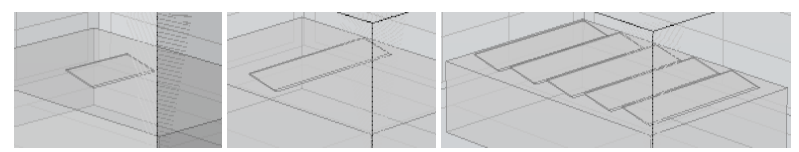

Fig. 1. Rooftop plan with photovoltaic panel structures 
turbulent flow interface $\mathrm{k}-\varepsilon$, commonly used to simulate single phase flows. The physical interface is adjusted for incompressible and low-Mach compressible flows (generally less than 0.3), which is a relationship between wind speed and sound speed [5].

The Navier-Stokes equations (1) to (7) govern fluid motion in the case of a compressible Newtonian fluid, where: $\rho$ is the density of the fluid; $u$ is the velocity of the field, where $u, v$ and $w$ are the vector components of wind velocity; $p$ is the pressure; $k$ is the turbulent kinetic energy; $\varepsilon$ is the dissipation rate of turbulence; $\mu$ is the dynamic viscosity; $c$ is the pressure coefficient; and $F$ represents the global force $[5]$.

$$
\begin{gathered}
\rho(\boldsymbol{u} . \nabla) \boldsymbol{u}=\nabla \cdot[-p \boldsymbol{I}+\boldsymbol{k}]+\boldsymbol{F} \\
\rho \nabla \cdot(\boldsymbol{u})=0 \\
\boldsymbol{k}=\left(\mu+\mu_{t}\right)\left(\nabla \boldsymbol{u}+(\nabla \boldsymbol{u})^{t}\right) \\
\rho(\boldsymbol{u} . \nabla) k=\nabla \cdot\left[\left(\mu+\frac{\mu_{t}}{\sigma_{k}}\right) \nabla k\right]+P_{k}-\rho \varepsilon \\
\rho(\boldsymbol{u} . \nabla) k=\nabla \cdot\left[\left(\mu+\frac{\mu_{t}}{\sigma_{k}}\right) \nabla \mathrm{k}\right]+C_{\varepsilon 1} \frac{\varepsilon}{k} p_{k} \\
-C_{\varepsilon 2} \rho \frac{\varepsilon^{2}}{k} \\
\mu_{t}=\rho C_{\mu} \frac{k^{2}}{\varepsilon} \\
P_{k}=\mu_{t}\left[\nabla \boldsymbol{u}:\left(\nabla \boldsymbol{u}+(\nabla \boldsymbol{u})^{t}\right)\right]
\end{gathered}
$$

In Brazil, ABNT NBR 6123 - Wind Forces in Buildings in section 5.1 defines as basic wind speed a gust lasting longer than $3 \mathrm{~s}$ that occurred on average once in 50 years, $10 \mathrm{~m}$ above ground, in an open field [4]. In this way, reference values are obtained for the building locality and the wind speeds and directions to be used in the computer simulations are defined. Thus, the basic wind speed of 35 $\mathrm{m} / \mathrm{s}$ in five flow directions is considered: $0^{\circ}, 45^{\circ}, 90^{\circ}, 180^{\circ}$ and $225^{\circ}$, as shown in Fig. 2. It is so important to observe that the directions set to $0^{\circ}$ and $180^{\circ}$ represent the front and rear directions relative to the panel, respectively. After these analyzes, the initial wind flow velocity is changed to $50 \mathrm{~m} / \mathrm{s}$, since this velocity is the highest reference speed in Brazil [2], [4].

From the definition and identification of wind flow directions, the Finite Element Method also provides the creation of a mesh that divides the geometry into small elements. The mesh used in all simulations present in this work is of tetrahedral format, with several refinement forms, which tend to vary according to the requirement and / or definition. The smaller the tetrahedron dimension, the greater the accuracy of the simulation. However, it implies greater computational effort. Figure 3 shows a meshing image for a given geometry.

For the mesh presented and used in the simulations, a normal size is set for both the building and the photovoltaic panels and the wind (space environment). However, these three domains of study differ in physics to be simulated. While the wind domain is calibrated to simulate with fluid dynamics, the building and photovoltaic panel domains are calibrated as general physics, thus characterizing the type of physics to be employed. For the fluid the maximum and minimum

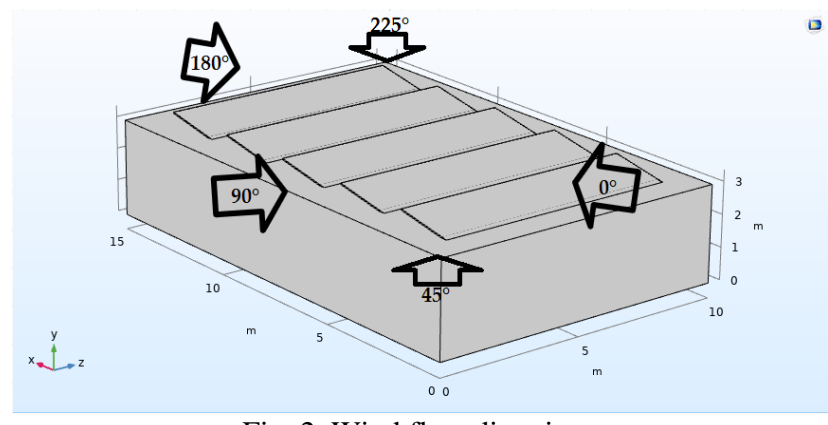

Fig. 2. Wind flow directions

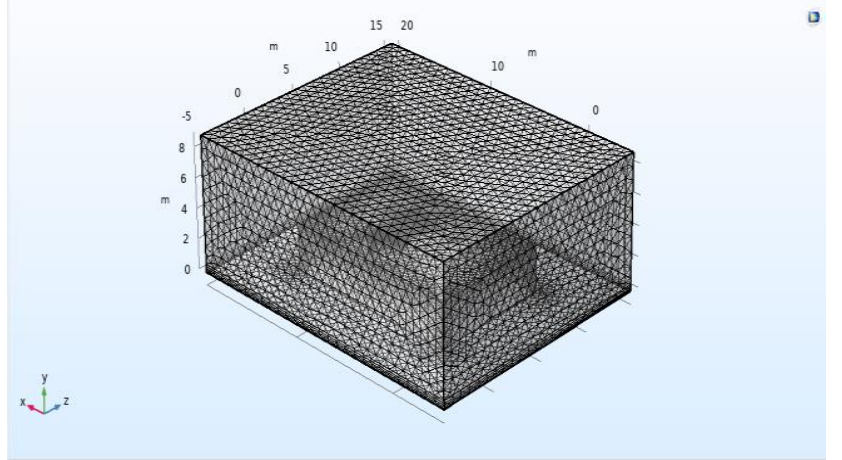

Fig.3. Mesh produced for given geometry

dimensions for the meshes generated are $0.899 \mathrm{~m}$ and 0.268 $\mathrm{m}$, respectively. And for the building and the photovoltaic panels are $2.5 \mathrm{~m}$ and $0.45 \mathrm{~m}$, respectively.

After defining the mesh, the structure is ready for simulation, and then proceeds to evaluate the aspects involving the wind speed in the structure, as well as the pressures exerted on the photovoltaic panels installed on the flat surface of the building roof.

\section{Results}

Computer simulations are performed for three different panels structures, with five different wind directions, and at speeds of $35 \mathrm{~m} / \mathrm{s}$ and $50 \mathrm{~m} / \mathrm{s}$, resulting in a total of thirty simulations which are presented below. Due to lack of space, only part of the graphic results obtained with the highest velocities and pressures are presented.

\section{A. Structure with five sets of eight photovoltaic panels on plan rooftops}

The simulations performed for the structure with five sets of eight panels on the rooftop were performed at the speeds of $35 \mathrm{~m} / \mathrm{s}$ and $50 \mathrm{~m} / \mathrm{s}$ in the directions shown in Figure 2 .

In this structure, which resembles most current installations, where usefull the rooftop space is occupied by photovoltaic panels, an analysis of the effects of wind actions on the panels fixing structure becomes necessary. From the simulations performed, various information can be collected. However, the pressures on the panels and the speed that the wind assumes in contact with the structure are the focus of analysis at this time. The effects of the minimum and maximum pressures must be highlighted as they are linked to the drag and suction forces acting on the structure of the photovoltaic system. 


\section{1) Wind direction at $0^{\circ}$ and speed of $35 \mathrm{~m} / \mathrm{s}$}

In this simulation the pressures acting on the structure range from $1.8 * 10^{3} \mathrm{~Pa}$ (equivalent to $183.55 \mathrm{kgf} / \mathrm{m}^{2}$ ) to $-1.33 * 10^{-}$ ${ }^{3} \mathrm{~Pa}$ (equivalent to a suction pressure of $135.62 \mathrm{kgf} / \mathrm{m}^{2}$ ), as illustrated in Figure 4. However, it should be noted that these pressures act on isolated points of the structure.

In the first two sets of panels, enumerating from the wall where the wind strikes, as illustrated in Figure 5, the suction pressure ranges from $-1.33 * 10^{3} \mathrm{~Pa}$ to $-0.53 * 10^{3} \mathrm{~Pa}$ (equivalent to 135.62 and $54.04 \mathrm{kgf} / \mathrm{m}^{2}$ ). In the last three sets of panels the pressures are still suction, but their values are less intense than those of the first panels, ranging from $-0.37 * 10^{3} \mathrm{~Pa}$ to $-0.21 * 10^{3} \mathrm{~Pa}$ (equivalent to 37.72 and 21.41 $\mathrm{kgf} / \mathrm{m}^{2}$ ).

The speed that moves in the $\mathrm{x}$-axis direction, ie, parallel to the building, as shown in Figure 5, ranges from $49.9 \mathrm{~m} / \mathrm{s}$ to $0.02 \mathrm{~m} / \mathrm{s}$. Note that in the first panels the speed is in the range of $5 \mathrm{~m} / \mathrm{s}$ and, as the wind progresses over the roof surface, the speed increases at the sides of the building, reaching the $30 \mathrm{~m} / \mathrm{s}$ range, close to the set wind speed.

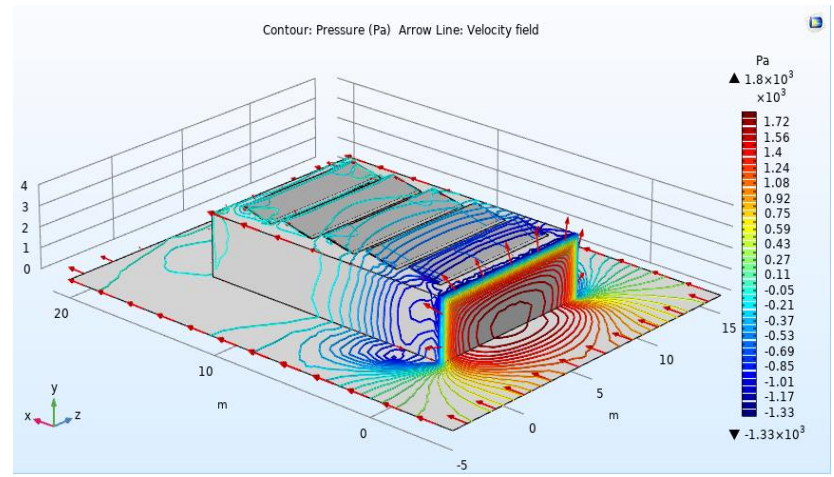

Fig. 4. Wind pressure acting on the building at $0^{\circ}$ direction

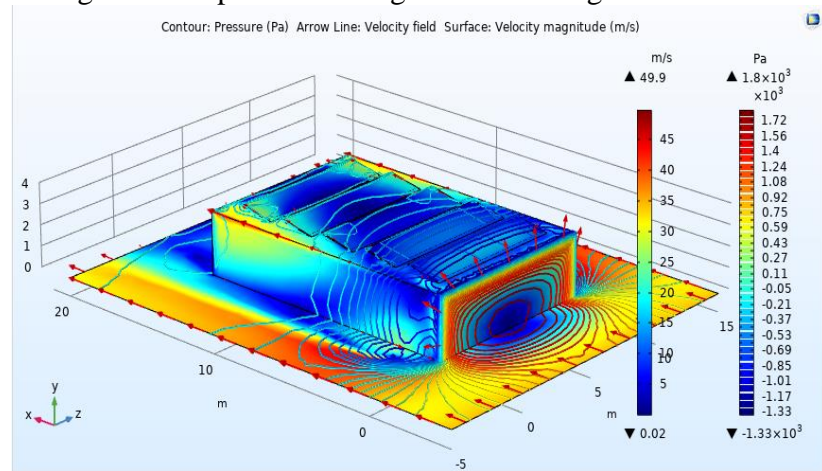

Fig. 5. Surface speed at $0^{\circ}$ direction

\section{2) Wind direction at $45^{\circ}$ and speed of $35 \mathrm{~m} / \mathrm{s}$}

For this simulation with $45^{\circ}$ wind incidence the pressures range from $1.89 * 10^{3} \mathrm{~Pa}$ (equivalent to $192.73 \mathrm{kgf} / \mathrm{m}^{2}$ ) to $1.53 * 10^{3} \mathrm{~Pa}$ (equivalent to a suction pressure of 156.02 $\mathrm{kgf} / \mathrm{m}^{2}$ ) as shown in Figure 6. Note that the pressure in the central part of the panels is positive with the tendency to drag it, and this pressure is in the range of $0.04 * 10^{3} \mathrm{~Pa}$ (equivalent to $4.07 \mathrm{kgf} / \mathrm{m}^{2}$ ). The pressures on the sides of the panel (in the outline of the panel, are characterized as being suction and are of the order of $-0.22 * 10^{3} \mathrm{~Pa}$ (equivalent to $22.43 \mathrm{kgf} / \mathrm{m}^{2}$ ).

As for the speed on the surface of the building presented in Figure 7, this ranges from $50.9 \mathrm{~m} / \mathrm{s}$ to $0.2 \mathrm{~m} / \mathrm{s}$. Note

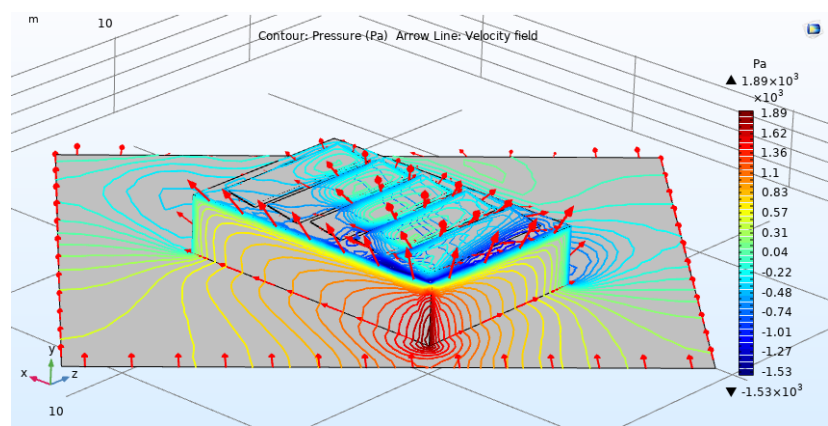

Fig.6. Wind pressure acting on the building at $45^{\circ}$ direction

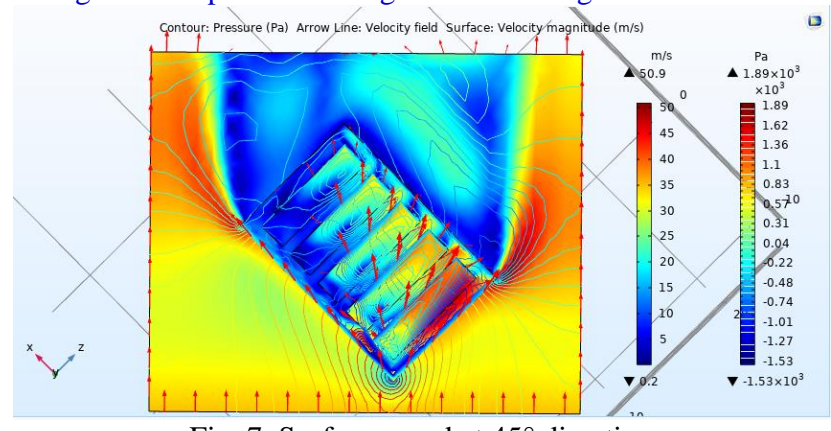

Fig. 7. Surface speed at $45^{\circ}$ direction

that speeds are higher at the rear of the panel than at the front, being higher in the first sets, significantly decreasing over the course of the building.

\section{3) Wind direction at $90^{\circ}$ and speed of $35 \mathrm{~m} / \mathrm{s}$}

For wind simulation on the building in the $90^{\circ}$ direction the maximum pressure is $2.24 * 10^{3} \mathrm{~Pa}$ (equivalent to a pressure of $228.42 \mathrm{kgf} / \mathrm{m}^{2}$ ) while the minimum is $-2.01 * 10^{3} \mathrm{~Pa}$ (equivalent to a pressure of $204.96 \mathrm{kgf} / \mathrm{m}^{2}$ ), as shown in Figure 8. As for the panels, it should be noted that the pressure on them is lower at the point closest to the wind application point. This is due to the change in direction and wind speed gain when it collides with the building on the wall represented by the $x y$ plane. Note the length of the red arrows representing the wind direction after contact with the structure. Then the suction pressures acquire a maximum value of $-0.27 * 10^{3} \mathrm{~Pa}$ (equivalent to a pressure of $27.53 \mathrm{kgf} / \mathrm{m}^{2}$ ) and a minimum value of $-1.14 * 10^{3} \mathrm{~Pa}$ (equivalent to a pressure of $116.25 \mathrm{kgf} / \mathrm{m}^{2}$ ).

As for the speed on the surface of the building, as shown

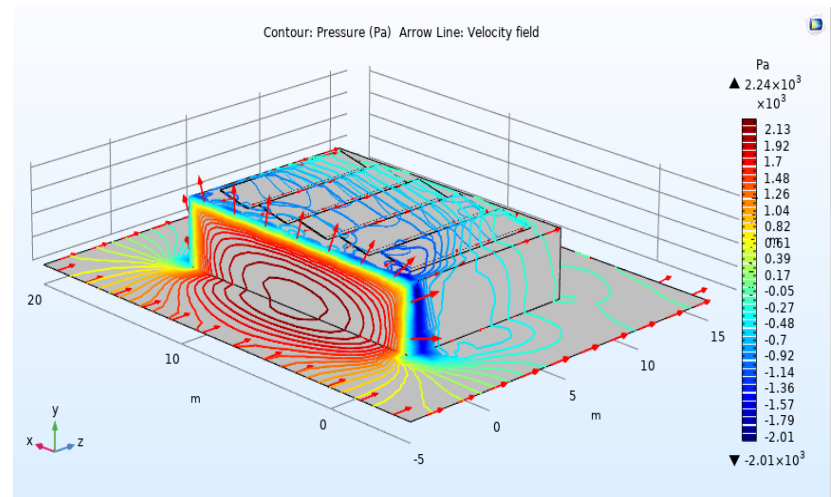

Fig. 8. Wind pressure acting on the building at $90^{\circ}$ direction 


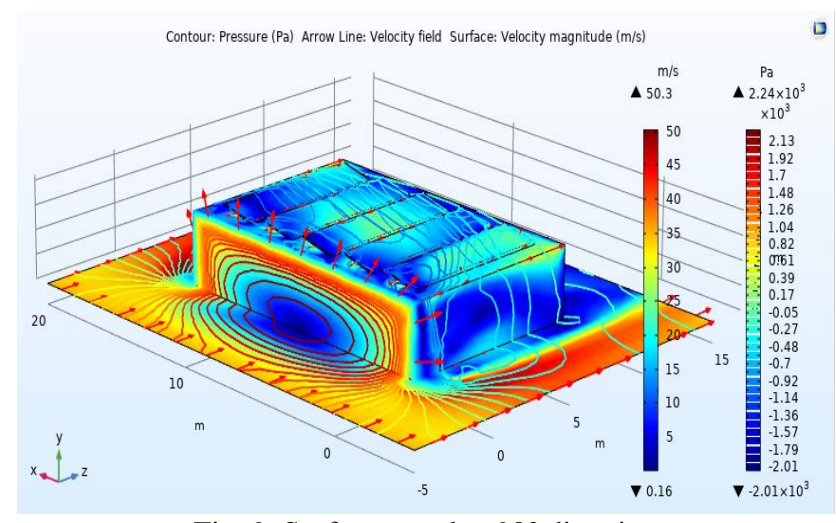

Fig. 9. Surface speed at $90^{\circ}$ direction

in Figure 9, varies from 50.3 to $0.16 \mathrm{~m} / \mathrm{s}$, with the highest speeds being in the wall where the wind collides. Note that the speed along the panel increases from $8 \mathrm{~m} / \mathrm{s}$ to around of $20 \mathrm{~m} / \mathrm{s}$. This is justified by the change in wind direction after collision with the panels, as identified by the red arrows in the image.

\section{4) Wind direction at $180^{\circ}$ and speed of $35 \mathrm{~m} / \mathrm{s}$}

The incidence of wind in the $180^{\circ}$ direction corresponds to the wind applied to the rear of the panels as shown in Figure 10. The resulting pressures range from $1.81 * 10^{3} \mathrm{~Pa}$ (equivalent to $184.57 \mathrm{kgf} / \mathrm{m}^{2}$ ) to $-1.27 * 10^{3} \mathrm{~Pa}$ (equivalent to a suction pressure of $129.5 \mathrm{kgf} / \mathrm{m}^{2}$ ). Note that the cover pressures closest to the wind collision wall are lower, also due to the change in wind direction after the collision with the building (illustrated by the red arrows). The pressures acting on the panels range from $-1.12 * 10^{3} \mathrm{~Pa}$ (equivalent to a suction pressure of $114.21 \mathrm{kgf} / \mathrm{m}^{2}$ ) to $0.15^{*} 10^{3} \mathrm{~Pa}$ (equivalent to a pressure of $15.3 \mathrm{kgf} / \mathrm{m}^{2}$ ).

The speeds on the building surface range from 50.4 to

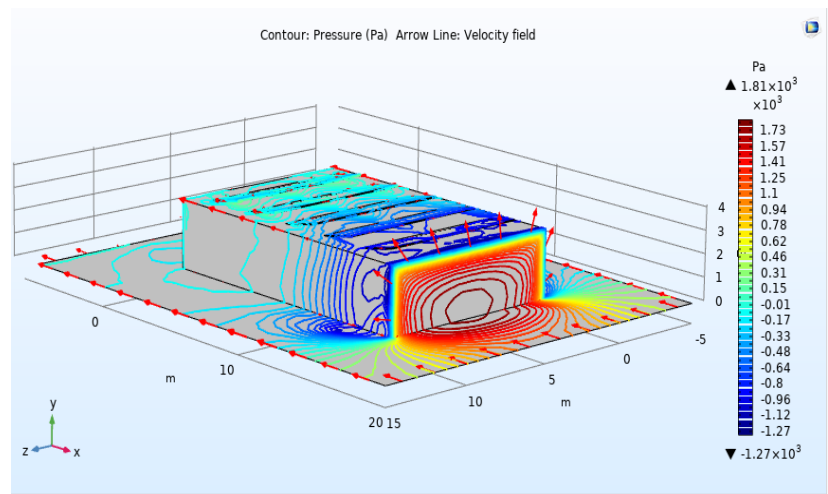

Fig. 10. Wind pressure acting on the building at $180^{\circ}$ direction

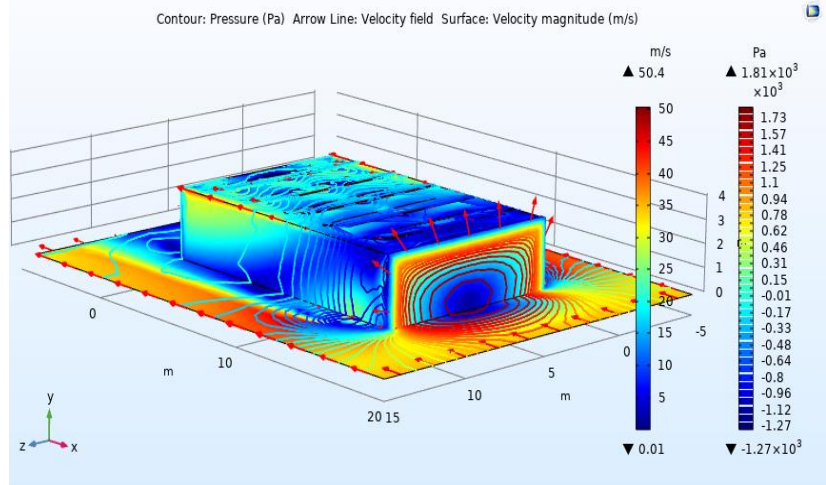

Fig. 11. Surface speed at $180^{\circ}$ direction
$0.01 \mathrm{~m} / \mathrm{s}$, as illustrated in Figure 11 .

Note that the speeds are higher along the structure, being higher at the end compared to the wind point of incidence.

\section{5) Wind direction at $225^{\circ}$ and speed of $35 \mathrm{~m} / \mathrm{s}$}

For these wind conditions on the building the maximum identified pressure is $1.43 * 10^{3} \mathrm{~Pa}$ (equivalent to a pressure of $145.82 \mathrm{kgf} / \mathrm{m}^{2}$ ) and the minimum pressure is $-1.33 * 10^{3}$ $\mathrm{Pa}$ (equivalent to a suction pressure of $135.62 \mathrm{kgf} / \mathrm{m}^{2}$ ), as shown in Figure 12. The greatest pressures are exerted on the panels closest to the roof edge where the wind initially hits the structure. This feature can be seen from the yellow color on the panels surface of Figure 12. Thus, the maximum pressure on the panels is $0.58 * 10^{3} \mathrm{~Pa}$ (equivalent to $59.14 \mathrm{kgf} / \mathrm{m}^{2}$ ) and the minimum pressure is $-0.69 * 10^{3} \mathrm{~Pa}$ (equivalent to a suction pressure of $70.36 \mathrm{kgf} / \mathrm{m}^{2}$ ).

As for the velocities on the surface of the analyzed structure, in the $x z$ plane, as illustrated in Figure 13, these vary from 46.8 to $0.07 \mathrm{~m} / \mathrm{s}$, acquiring higher values at the edges of the building and at the bottom of the panels, due to the obstacle they represent for wind circulation.

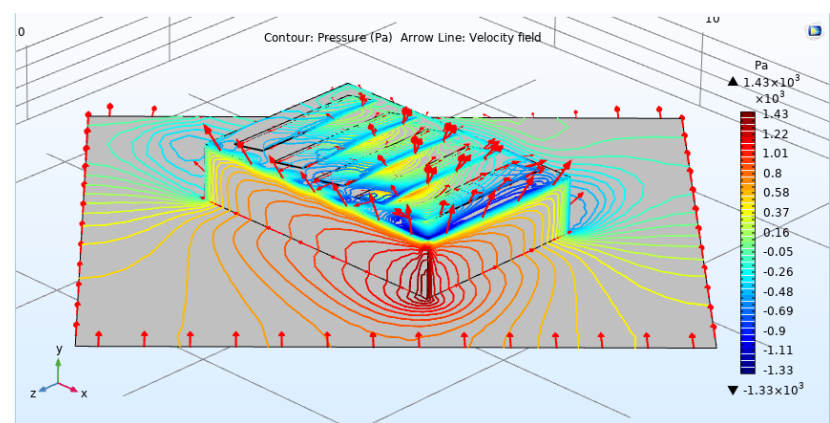

Fig.12. Wind pressure acting on the building at $225^{\circ}$ direction

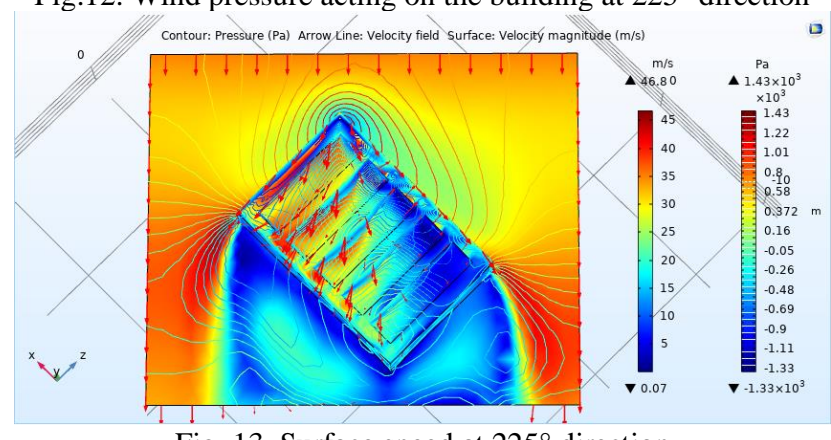

Fig. 13. Surface speed at $225^{\circ}$ direction

B. Structure with four and eight photovoltaic panels on plan rooftops

From the results obtained and presented so far, they are now analyzed for structures consisting of four and eight photovoltaic panels for wind incidence in the direction of $225^{\circ}$.

As illustrated by Figure 14, the wind falling on the four panels photovoltaic structure assumes an upward deviation, represented by the red arrows, due to the obstacle that the photovoltaic panel represents for the free movement of the wind. Moreover, in the same Figure 14, it is observed that the pressures on the panels are higher at the bottom, that is, the wind tends to tear off the panels when it hits the rear, as opposed to the top at the panel. 
The pressures in the simulation range from $-125 * 10^{3}$ to $1.35^{*} 10^{3} \mathrm{~Pa}$, equivalent to -127.46 and $137.66 \mathrm{kgf} / \mathrm{m}^{2}$, respectively. While pressures at the top of the panel range from $-0.65^{*} 10^{3}$ to $0.15^{*} 10^{3} \mathrm{~Pa}$, equivalent to -66.28 and $15.29 \mathrm{kgf} / \mathrm{m}^{2}$, and at the bottom, they range from $0.15^{*} 10^{3}$ to $0.55^{*} 10^{3} \mathrm{~Pa}$, equivalent to 15.29 and $56.08 \mathrm{kgf} / \mathrm{m}^{2}$, respectively.

Figure 15 presents the characteristics of the wind speed on the building surface and ranges from 0.77 to $45.6 \mathrm{~m} / \mathrm{s}$. The highest speed is identified after the photovoltaic panel and the lowest speeds are present in the contour of the building. This is due to the direction that the wind takes shortly after colliding with the structure (upward flow), as shown by red arrows in the Figure 15. This results in a decrease in wind speed at the roof surface immediately after the edge of the building.

Similarly, a maximum pressure of $1.36 * 10^{3} \mathrm{~Pa}$ (equivalent to $138.68 \mathrm{kgf} / \mathrm{m}^{2}$ ) and a minimum pressure of $-2 * 10^{3} \mathrm{~Pa}$ (equivalent to a suction pressure of $203.94 \mathrm{kgf} / \mathrm{m}^{2}$ ) are obtained for the eight panels structure, as shown in Figure 16. Pay attention to the pressure difference at the bottom of the PV array. This justifies the importance of analyzing this wind direction as the wind will reach the rear of the panel resulting in a positive pressure of approximately $0.26 * 10^{3}$ $\mathrm{Pa}$ (equivalent to $26.51 \mathrm{kgf} / \mathrm{m}^{2}$ ). This proves the need to use suitable devices for fixing the panels to the rooftop of the building.

Finally, in Figure 17 it is possible to evaluate the velocity on the surface of the structure. For this case, the maximum speed is $51.7 \mathrm{~m} / \mathrm{s}$ and the minimum is $0.32 \mathrm{~m} / \mathrm{s}$. Note that

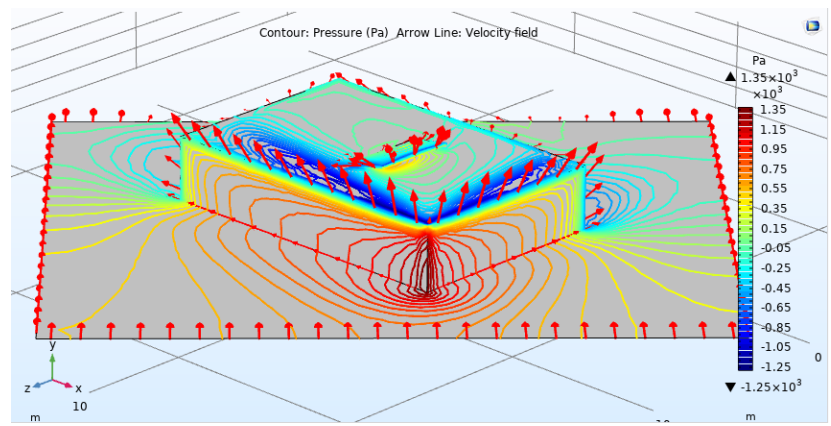

Fig. 14. Wind pressure acting on the building at $225^{\circ}$ direction - four photovoltaic panels

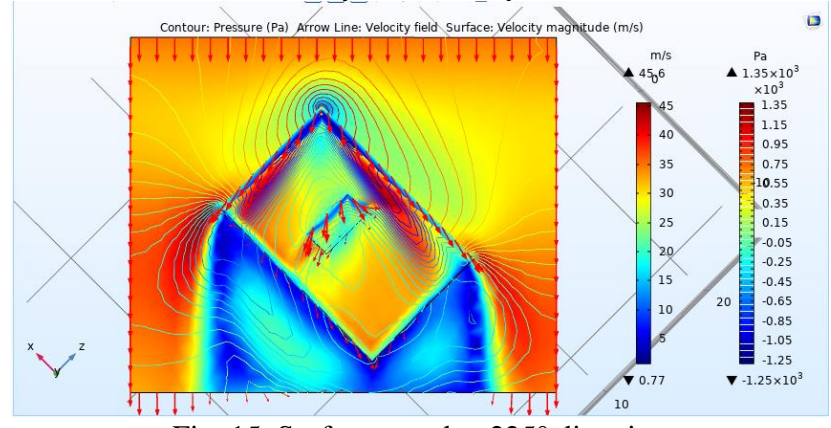

Fig. 15. Surface speed at $225^{\circ}$ direction - four photovoltaic panels

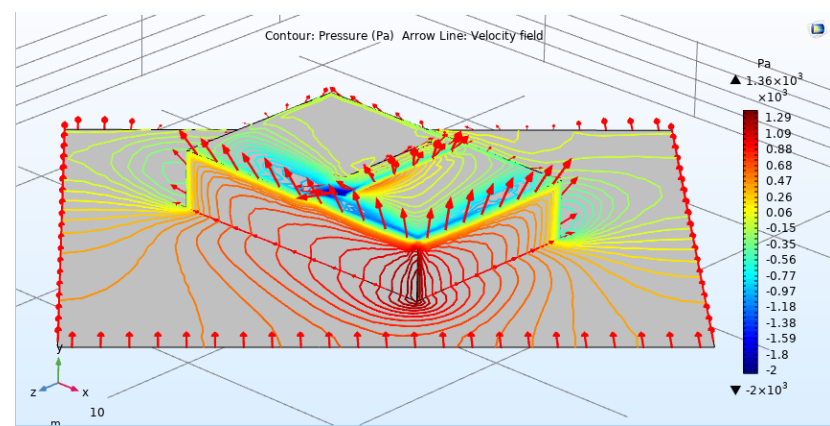

Fig. 16. Wind pressure acting on the building at $225^{\circ}$ direction - eight photovoltaic panels

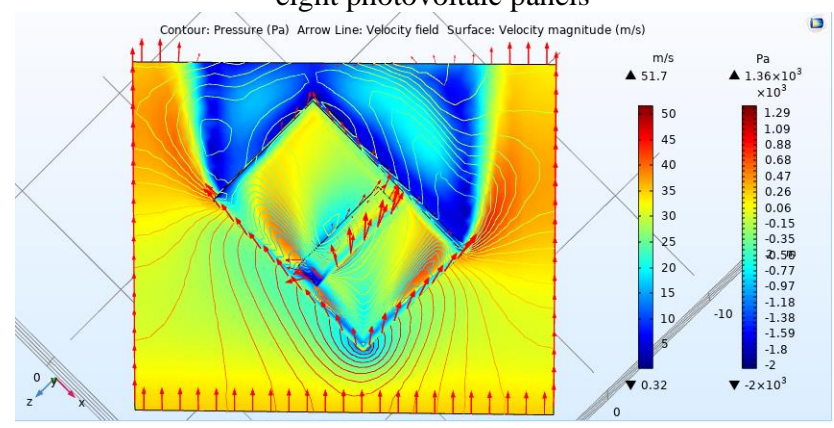

Fig. 17. Surface speed at $225^{\circ}$ direction - eigth photovoltaic panels

unlike other simulations, the speed is relatively low on the front of the panels. Something similar is observed for the $180^{\circ}$ wind direction, but less strongly than for the $225^{\circ}$ wind direction.

\section{Summary of results obtained}

The results presented so far in this article are for wind speed of $35 \mathrm{~m} / \mathrm{s}$, which is the typical maximum speed at the central region of Brazil. To meet the maximum speed of 50 $\mathrm{m} / \mathrm{s}$, the same simulations were also performed so that the information of the pressures exerted on the defined structures can be verified. The results obtained are presented in Table I, Table II and Table III, which correspond to the set of four panels, the set of eight panels and the structure with five sets of eight panels each. In the tables the results for the maximum and minimum speeds and pressures for each wind direction can be identified.

\section{Conclusion}

This article aimed to analyze the velocities and pressures that wind exerts in three different configurations of photovoltaic systems installed on flat rooftops of buildings. From the results obtained for different wind intensities and directions it can be seen that the wind in the $225^{\circ}$ directions are responsible for the largest forces acting on the structures to pull the structures fixed on the flat rooftops. Thus, it can be concluded that software based on the finite element method assists in the analysis of wind effects on photovoltaic structures installed on building roofs. It can still be stated that studies involving the sloping roofs and the materials used to fix the metal structure and photovoltaic panels are necessary. And finally, from the results, it is affirmed about the necessity of the proper fixation of the structure in order to withstand 
Table I - Structure with one set of four photovoltaic panels at 35 and $50 \mathrm{~m} / \mathrm{s}$

\begin{tabular}{|c|c|c|c|c|}
\hline $35 \mathrm{~m} / \mathrm{s}$ & \multicolumn{2}{|c|}{ Speed (m/s) } & \multicolumn{2}{c|}{ Pressure $\left(\mathrm{Pa}-\mathrm{kgf} / \mathrm{m}^{2}\right)$} \\
\hline Direction & Maximum & Minimum & Maximum & Minimum \\
\hline $0^{\circ}$ & 51 & 0.03 & $0.2^{*} 10^{3} \mathrm{~Pa}-20.39 \mathrm{kgf} / \mathrm{m}^{2}$ & $-0.37 * 10^{3} \mathrm{~Pa}--37.72 \mathrm{kgf} / \mathrm{m}^{2}$ \\
\hline $45^{\circ}$ & 49.8 & 0.23 & $-0.49^{*} 10^{3} \mathrm{~Pa}--49.96 \mathrm{kgf} / \mathrm{m}^{2}$ & $0.03 * 10^{3} \mathrm{~Pa}-3.05 \mathrm{kgf} / \mathrm{m}^{2}$ \\
\hline $90^{\circ}$ & 54.2 & 0.1 & $-0.55^{*} 10^{3} \mathrm{~Pa}--56.08 \mathrm{kgf} / \mathrm{m}^{2}$ & $-0.94 * 10^{3} \mathrm{~Pa}--95.85 \mathrm{kgf} / \mathrm{m}^{2}$ \\
\hline $180^{\circ}$ & 50.7 & 0.24 & $-0.2^{*} 10^{3} \mathrm{~Pa}--20.71 \mathrm{kgf} / \mathrm{m}^{2}$ & $-0.52^{*} 10^{3} \mathrm{~Pa}--53.02 \mathrm{kgf} / \mathrm{m}^{2}$ \\
\hline $225^{\circ}$ & 45.6 & 0.77 & $0.15^{*} 10^{3} \mathrm{~Pa}-15.29 \mathrm{kgf} / \mathrm{m}^{2}$ & $-0.45^{*} 10^{3} \mathrm{~Pa}--45.88 \mathrm{kgf} / \mathrm{m}^{2}$ \\
\hline $50 \mathrm{~m} / \mathrm{s}$ & \multicolumn{2}{|c|}{ Speed $(\mathrm{m} / \mathrm{s})$} & \multicolumn{2}{|c|}{$\mathrm{Pressure}\left(\mathrm{Pa}-\mathrm{kgf} / \mathrm{m}^{2}\right)$} \\
\hline $0^{\circ}$ & 73.5 & 0.08 & $-0.42^{*} 10^{3} \mathrm{~Pa}--42.83 \mathrm{kgf} / \mathrm{m}^{2}$ & $-0.75^{*} 10^{3} \mathrm{~Pa}--76.48 \mathrm{kgf} / \mathrm{m}^{2}$ \\
\hline $45^{\circ}$ & 71.5 & 0.12 & $0.14^{*} 10^{4} \mathrm{~Pa}-142.76 \mathrm{kgf} / \mathrm{m}^{2}$ & $-0.1^{*} 10^{4} \mathrm{~Pa}--101.97 \mathrm{kgf} / \mathrm{m}^{2}$ \\
\hline $90^{\circ}$ & 77.9 & 0.09 & $-0.75^{*} 10^{3} \mathrm{~Pa}--76.48 \mathrm{kgf} / \mathrm{m}^{2}$ & $-1.54^{*} 10^{3} \mathrm{~Pa}--157.04 \mathrm{kgf} / \mathrm{m}^{2}$ \\
\hline $180^{\circ}$ & 72.9 & 0.36 & $-0.4^{*} 10^{3} \mathrm{~Pa}--40.79 \mathrm{kgf} / \mathrm{m}^{2}$ & $-1.38^{*} 10^{3} \mathrm{~Pa}--140.72 \mathrm{kgf} / \mathrm{m}^{2}$ \\
\hline $225^{\circ}$ & 65.6 & 1.09 & $0.31^{*} 10^{3} \mathrm{~Pa}-31.61 \mathrm{kgf} / \mathrm{m}^{2}$ & $-1.32^{*} 10^{3} \mathrm{~Pa}--134.6 \mathrm{kgf} / \mathrm{m}^{2}$ \\
\hline
\end{tabular}

Table II - Structure with one set of eight photovoltaic panels at 35 and $50 \mathrm{~m} / \mathrm{s}$

\begin{tabular}{|c|c|c|c|c|}
\hline $35 \mathrm{~m} / \mathrm{s}$ & \multicolumn{2}{|c|}{ Speed $(\mathrm{m} / \mathrm{s})$} & \multicolumn{2}{|c|}{ Pressure $\left(\mathrm{Pa}-\mathrm{kgf} / \mathrm{m}^{2}\right)$} \\
\hline Direction & Maximum & Minimum & Maximum & Minimum \\
\hline $0^{\circ}$ & 50.4 & 0.08 & $-0.18 * 10^{3} \mathrm{~Pa}--18.35 \mathrm{kgf} / \mathrm{m}^{2}$ & $-0.34 * 10^{3} \mathrm{~Pa}--34.67 \mathrm{kgf} / \mathrm{m}^{2}$ \\
\hline $45^{\circ}$ & 54.9 & 0.06 & $-0.03 * 10^{3} \mathrm{~Pa}--3.05 \mathrm{kgf} / \mathrm{m}^{2}$ & $-0.87 * 10^{3} \mathrm{~Pa}--88.71 \mathrm{kgf} / \mathrm{m}^{2}$ \\
\hline $90^{\circ}$ & 54.3 & 0.19 & $-0.02 * 10^{3} \mathrm{~Pa}--2.03 \mathrm{kgf} / \mathrm{m}^{2}$ & $-1 * 10^{3} \mathrm{~Pa}--101.97 \mathrm{kgf} / \mathrm{m}^{2}$ \\
\hline $180^{\circ}$ & 50.6 & 0.11 & $-0.21 * 10^{3} \mathrm{~Pa}--21.41 \mathrm{kgf} / \mathrm{m}^{2}$ & $-0.69 * 10^{3} \mathrm{~Pa}-70.36 \mathrm{kgf} / \mathrm{m}^{2}$ \\
\hline $225^{\circ}$ & 51.7 & 0.32 & $0.06 * 10^{3} \mathrm{~Pa}-6.11 \mathrm{kgf} / \mathrm{m}^{2}$ & $-1.59 * 10^{3} \mathrm{~Pa}--162.13 \mathrm{kgf} / \mathrm{m}^{2}$ \\
\hline $50 \mathrm{~m} / \mathrm{s}$ & \multicolumn{2}{|c|}{ Speed $(\mathrm{m} / \mathrm{s})$} & \multicolumn{2}{|c|}{ Pressure $\left(\mathrm{Pa}-\mathrm{kgf} / \mathrm{m}^{2}\right)$} \\
\hline $0^{\circ}$ & 72.6 & 0.06 & $-0.33 * 10^{3} \mathrm{~Pa}--33.65 \mathrm{kgf} / \mathrm{m}^{2}$ & $-0.65 * 10^{3} \mathrm{~Pa}--66.28 \mathrm{kgf} / \mathrm{m}^{2}$ \\
\hline $45^{\circ}$ & 71.5 & 0.27 & $-0.25 * 10^{3} \mathrm{~Pa}--25.49 \mathrm{kgf} / \mathrm{m}^{2}$ & $-1.55 * 10^{3} \mathrm{~Pa}--158.06 \mathrm{kgf} / \mathrm{m}^{2}$ \\
\hline $90^{\circ}$ & 78.1 & 0.17 & $-0.44 * 10^{3} \mathrm{~Pa}--44.86 \mathrm{kgf} / \mathrm{m}^{2}$ & $-1.64 * 10^{3} \mathrm{~Pa}--167.23 \mathrm{kgf} / \mathrm{m}^{2}$ \\
\hline $180^{\circ}$ & 72.9 & 0.15 & $-0.73 * 10^{3} \mathrm{~Pa}--74.43 \mathrm{kgf} / \mathrm{m}^{2}$ & $-1.06 * 10^{3} \mathrm{~Pa}-108.09 \mathrm{kgf} / \mathrm{m}^{2}$ \\
\hline $225^{\circ}$ & 74.6 & 0.43 & $0.13 * 10^{3} \mathrm{~Pa}-13.25 \mathrm{kgf} / \mathrm{m}^{2}$ & $-2.49 * 10^{3} \mathrm{~Pa}--253.91 \mathrm{kgf} / \mathrm{m}^{2}$ \\
\hline
\end{tabular}

Table III - Structure with five sets of eight photovoltaic panels at 35 and $50 \mathrm{~m} / \mathrm{s}$

\begin{tabular}{|c|c|c|c|c|}
\hline $35 \mathrm{~m} / \mathrm{s}$ & \multicolumn{2}{|c|}{ Speed $(\mathrm{m} / \mathrm{s})$} & \multicolumn{2}{c|}{ Pressure $\left(\mathrm{Pa}-\mathrm{kgf} / \mathrm{m}^{2}\right)$} \\
\hline Direction & Maximum & Minimum & Maximum & Minimum \\
\hline $0^{\circ}$ & 49.9 & 0.02 & $-0.21^{\circ} 10^{3} \mathrm{~Pa}--21.41 \mathrm{kgf} / \mathrm{m}^{2}$ & $-1.33 * 10^{3} \mathrm{~Pa}--135.62 \mathrm{kgf} / \mathrm{m}^{2}$ \\
\hline $45^{\circ}$ & 50.9 & 0.2 & $0.04 * 10^{3} \mathrm{~Pa}-4.07 \mathrm{kgf} / \mathrm{m}^{2}$ & $-1.27 * 10^{3} \mathrm{~Pa}--129.5 \mathrm{kgf} / \mathrm{m}^{2}$ \\
\hline $90^{\circ}$ & 50.3 & 0.16 & $-0.27 * 10^{3} \mathrm{~Pa}-27.53 \mathrm{kgf} / \mathrm{m}^{2}$ & $-1.14^{*} 10^{3} \mathrm{~Pa}--116.25 \mathrm{kgf} / \mathrm{m}^{2}$ \\
\hline $180^{\circ}$ & 50.4 & 0.01 & $0.15^{*} 10^{3} \mathrm{~Pa}-15.29 \mathrm{kgf} / \mathrm{m}^{2}$ & $-1.12^{*} 10^{3} \mathrm{~Pa}--114.21 \mathrm{kgf} / \mathrm{m}^{2}$ \\
\hline $225^{\circ}$ & 46.8 & 0.07 & $0.58 * 10^{3} \mathrm{~Pa}-59.14 \mathrm{kgf} / \mathrm{m}^{2}$ & $-0.9 * 10^{3} \mathrm{~Pa}--91.77 \mathrm{kgf} / \mathrm{m}^{2}$ \\
\hline $50 \mathrm{~m} / \mathrm{s}$ & \multicolumn{2}{|c|}{ Speed $(\mathrm{m} / \mathrm{s})$} & \multicolumn{2}{|c|}{$\mathrm{Pressure}\left(\mathrm{Pa}-\mathrm{kgf} / \mathrm{m}^{2}\right)$} \\
\hline $0^{\circ}$ & 71.9 & 0.03 & $-0.09^{*} 10^{3} \mathrm{~Pa}--9.17 \mathrm{kgf} / \mathrm{m}^{2}$ & $-2.06^{*} 10^{3} \mathrm{~Pa}--210.06 \mathrm{kgf} / \mathrm{m}^{2}$ \\
\hline $45^{\circ}$ & 73 & 0.31 & $0.09^{3} 10^{3} \mathrm{~Pa}-9.17 \mathrm{kgf} / \mathrm{m}^{2}$ & $-2.05^{*} 10^{3} \mathrm{~Pa}--209.04 \mathrm{kgf} / \mathrm{m}^{2}$ \\
\hline $90^{\circ}$ & 77.3 & 0.04 & $-0.65^{*} 10^{3} \mathrm{~Pa}--66.28 \mathrm{kgf} / \mathrm{m}^{2}$ & $-1.83 * 10^{3} \mathrm{~Pa}--186.61 \mathrm{kgf} / \mathrm{m}^{2}$ \\
\hline $180^{\circ}$ & 72.6 & 0.02 & $0.3 * 10^{3} \mathrm{~Pa}-30.6 \mathrm{kgf} / \mathrm{m}^{2}$ & $-1.95^{*} 10^{3} \mathrm{~Pa}--198.84 \mathrm{kgf} / \mathrm{m}^{2}$ \\
\hline $225^{\circ}$ & 64.3 & 0.25 & $1.25^{*} 10^{3} \mathrm{~Pa}-127.46 \mathrm{kgf} / \mathrm{m}^{2}$ & $-1.23^{*} 10^{3} \mathrm{~Pa}--125.43 \mathrm{kgf} / \mathrm{m}^{2}$ \\
\hline
\end{tabular}

the intense pressure exerted by the wind, especially in the rear of the panels, minimizing possible damages and accidents.

\section{Acknowledgement}

This article is the result of a research and development project sponsored by Enel Distribuição Goiás/Brazil and Federal Institute of Goiás/Brazil.

\section{References}

[1] ABSOLAR. ABSOLAR Infografic, number 12, 01/10/2019. Link: http://www.absolar.org.br/infografico-absolar-.html, accessed in 28/10/2019.

[2] Ferreira, Luiz G. G. B. "Numerical Analysis of Wind Actions in Photovoltaic Systems Installed on Rooftop of Buildings". Master's degree, Goiânia (2018), Brazil.
[3] Ferreira, L. G. G. B.; Domingos, J. L.; Alves, A. J. "Analysis of Tensions and Deformations of Fixing Supports of Photovoltaic Panels Installed on Rooftops". International Conference on Renewable Energy \& Power Quality Jornal (RE\&PQJ), Salamanca, Spain (2018), Vol. 01, p. 602-607.

[4] ABNT. "NBR 6123 - Wind Forces in Buildings". Brazilian Association of Technical Standards, Rio de Janeiro, Brazil (1988).

[5] COMSOL Multyphisics®, User’s Guide, 2019. 